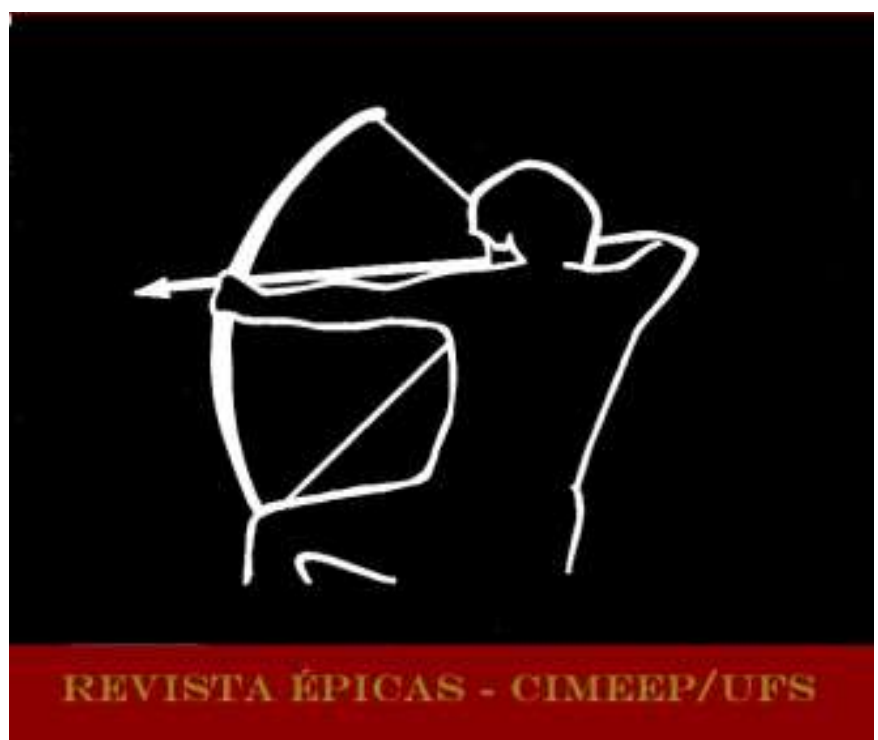

SILVA, Amós Coêlho da. Achegas sobre o simbolismo do epíteto. In: Revista Épicas. Ano 4, N. 8, Dez 2020, p. 168-186. ISSN 2527-080X. DOI: http://dx.doi.org/10.47044/2527-080X.2020v8.168186

\title{
ACHEGAS SOBRE O SIMBOLISMO DO EPÍTETO
}

\section{ADDITIONS ABOUT EPITHETIC SYMBOLISM}

\author{
Amós Coêlho da Silva ${ }^{1}$ \\ Universidade do Estado do Rio de Janeiro - UERJ
}

Preito a Junito de Souza Brandão:

"Sidus,-eris é constelação, donde considerare,'considerar', é "examinar atenta e respeitosamente os astros e sondar-lhes as disposições". Cícero já emprega a expressão sidera natalicia (De Diu. 2, 43, 91), 'astros que presidem aos nascimentos' e determinam as sequências da vida dos que nascem sob sua tutela." (BRANDÃO, Introdução: 15 v.l)

RESUMO: Formulações etimológicas do epíteto desde a épica clássica. Comparação entre o homem de outrora com o de hoje e entre sociedades arcaicas e primitivas, com recorrência a apontamentos teóricos de comentadores, mitógrafos e filósofos, para observar interdisciplinarmente a presença de alteridade nos diálogos. Em destaque o jogo intertextual no tempo histórico, evidenciando relações entre expressões poéticas e religiosas, para assinalar linha poética em formas épicas e de romances, ao lado do sagrado nos mitos. Conceito etimológico de epíteto no herói, no elemento divino e na ação ora divina, ora heroica, com realizações sublimadas ou com as criações astutas de trickster.

Palavras-chave: etimologia; epíteto; poesia; mito.

\footnotetext{
1 Professor Associado desde 2009 pela Universidade do Estado do Rio de Janeiro. E-mail: amoscoelho@uol.com.br.
} 
ABSTRACT: Etymological formulations of the epithet since the classic epic. Comparison between the man of yore and that of today and between archaic and primitive societies, with recurrence of theoretical notes from commentators, mythographers and philosophers, to interdisciplinarily observe the presence of otherness in the dialogues. Highlighted the intertextual game in historical time, showing relationships between poetic and religious expressions to mark a poetic line in epic and novel forms, to mark a poetic line in epic and novel forms, alongside the sacred in myths. Etymological concept of epithet in the hero, in the divine element and in action, sometimes divine, sometimes heroic, with sublimated achievements or with the cunning trickster creations.

Keywords: etymology; epithet; poetry; myth.

\section{Introdução}

A construção etimológica do epíteto na épica homérica projeta o que Emil Staiger sublinhou como sua essência fundamental: a apresentação. Ressalve-se, desde este início, que nem sempre nos debruçaremos sobre passagens de gênero épico para evidenciar caracterizações estilísticas típicas dele e que o principal escopo será realçar a exemplaridade épica de Homero se instalando, primeiramente, no texto da epopeia vergiliana, com a contingência do relato mítico, onde se amalgama com seus arquétipos míticos nos interstícios de novos horizontes, como a fundação das muralhas romanas e, depois, se imiscui, intertextualmente, em romances e em outras formulações de gênero literário.

Em uma das apresentações na Odisseia, temos a singularidade das lágrimas do herói, como aquelas de Odisseu, quando, no canto VIII, verso 531, pranteava ${ }^{2}$, como Mulher que chora sobre o corpo do marido (verso 523): entretanto, como enunciação homérica, somente o rei Alcínoo percebeu-Ihe o pranto. Este nobre rei dos feácios, dotado de discrição, não permitiu que alguém mais notasse. Não deixou seu hóspede sentir-se deslocado e encerrou a apresentação de Demódoco, para, em seguida, solicitar discretamente a revelação de sua identidade, até então oculta, como se lerá mais adiante, inclusive em outra passagem além, teremos em Gonçalves Dias, algo bem semelhante, inclusive quanto à significação das lágrimas.

Faremos, pois, frequentes cotejos, de múltiplos modos. Por exemplo, uns entre o homem de outrora em relação ao de hoje; outros, entre civilizações e comunidades arcaicas e primitivas com identidades totalmente diferentes, a fim de obter fundamentação interdisciplinar, retirando de culturas díspares o máximo de alteridade, bem como o mais exemplar no jogo intertextual de interlocução nos seus diálogos e nas suas linguagens.

\footnotetext{
2 Utilizamos aqui a tradução de Trajano Vieira.
} 
Em Gênesis 2:20, há um indicativo da força significativa do "nome", quando Javé Deus chamou o homem para nomear os animais: O homem deu então nome a todos animais. Nas duas menções bíblicas (Isaías 7:14; Mateus 1:23), Emanuel, significando Deus conosco, é uma respeitosa saudação ao nome.

Por isso, precisamos indagar por que Graciliano Ramos (1892 - 1953) não pôs nomes nos filhos e a comunicação é indicada apenas como "menino mais velho" e "menino mais novo", e até se destacam como dois capítulos, o V e o VI, só assim intitulados. Mas a cachorra tem um nome: Baleia. Esta passagem literária vai além do termo "infante", dicionarizada, a partir do latim infans, infantis, aquele que não fala. Historicamente, como bem o aponta Houaiss Eletrônico: em Portugal e Espanha, filho de reis, porém não herdeiro do trono.

Uma situação emblemática de linguagem, pois os adultos se relacionavam desse modo com as crianças de outrora. Entre nós modernos, inclusive menosprezando uma ação infantil na vida doméstica mantivemos interruptores, maçanetas de portas etc., por longa data, fora do seu alcance, mesmo quando eles já contavam com certa idade.

No caso de Vidas Secas, isso se dá emblematicamente devido ao obscurantismo social das crianças nordestinas, se levarmos em conta o fato de a cachorra Baleia se projetar pelo próprio nome dela entre os adultos nordestinos. O outro que completava a família era o papagaio. Dele se fala logo no primeiro capítulo, num discurso indireto livre com a marca do pretérito mais-queperfeito e sem a formalização expressa do pronome sujeito, cuja conotação é a importância do nome ou competência da palavra e reproduz precisamente o pensamento de Sinhá Vitória:

Resolvera de supetão aproveitá-lo como alimento e justificara-se declarando a si mesma que ele era mudo e inútil. Não podia deixar de ser mudo. Ordinariamente a família falava pouco. E depois daquele desastre viviam todos calados, raramente soltavam palavras curtas. O louro aboiava, tangendo um gado inexistente, e latia arremedando a cachorra.

Note-se também o louro em peculiar segregação, e, portanto, o seu valor simbólico, num jogo da força da tradição do juízo coletivo, aliviando a culpa do crime, Sinhá Vitória se liberta ou se purifica nesta sua subjetivação.

Platão (427 a 346 a.C.), no seu diálogo Crátilo, faz reflexões sobre questões etimológicas do nome, as quais já remontam a uma preocupação homérica. Note-se também que o termo etimologia que significava para os antigos 'étimon légein', dizer a verdade, o que levou Cícero 
(Pro Cluentio 130) a traduzir em latim por "veriloquium, notatio", (dizer a verdade / ação de marcar com um sinal). Como sói, Sócrates, seu mestre, participa como mediador, mas observando a cilada na origem da palavra, quer se tome as ilações da personagem Crátilo que defende o princípio de imposição da linguagem aos homens por necessidade da natureza ('phýsis'), quer se tome sua imposição por costume, convenção ('nómos'/'thésis'), conforme a personagem Hermógenes. Há uma insatisfação irônica nas interpelações socráticas do texto platônico em tela: busca-se uma autêntica verdade do "ser", no sentido de 'ousía'/ 'gígnomai'.

\section{Mito e nome}

Com efeito, um poema, que, em grego 'poíema' é coisa feita; invenção, se aproxima bastante do mito, inclusive no sentido de 'mýthos', palavra, discurso... Dito de outro modo: a verdade poética ou mítica são caminhos simbólicos para revelação do real ao homem, seja quanto à sua subjetivação como reação coletiva ou individual. É assim, em menino mais velho e menino mais novo de Graciliano Ramos. Eles não são, como diria Durval Muniz, um expurgo, dado o discurso oligárquico que se escarnece, atualizando imagens e estereótipos em relação ao nordestino na mídia e memória do sul e sudeste brasileiro. Eles, de fato, são a separação das linguagens, conforme a Pax culturalis, como a conceituou Roland Barthes: o não compartilhamento da interação social entre polos de linguagem que se excluem, como entre a do nordestino e a do sudeste ou sul. No dizer de Barthes: a cultura é, de certa maneira, o campo patológico por excelência onde se inscreve a alienação do homem contemporâneo (palavra certa, a uma só vez social e mental). (1986: 107. Grifo do Autor)

No poema épico ${ }^{3}$, de João Cabral de Melo Neto (1920 - 1999), Auto do Frade Frei temos uma representação de rivalidade, no sentido de separação de linguagens e luto permanente (Idem, ibidem: 106) entre os aliados sul e sudeste contra o nordeste, como teorização de Barthes em seu ensaio de 1971: A Paz Cultural.

A propósito do termo separação, tomemos brevemente Erich Fromm, in A Arte de Amar: O homem - de todas as idades e culturas - vê-se diante da solução de uma e mesma questão: a

\footnotetext{
3 Épico é formado do grego, um derivado de 'épos', palavra, narrativa; portanto, a questão do “nome”. (MOISÉS: ÉPICA)
} 
de como superar a separação, a de como realizar a união, a de como transcender a própria vida individual e encontrar sintonia.

Daí, nos eventos míticos, como se lê em Brandão, v.III, p. 23, os ritos iniciáticos:

Separando-se dos seus e, após longos ritos iniciáticos, o herói inicia suas aventuras, a partir de proezas comuns num mundo de todos os dias, até chegar a uma região de prodígios sobrenaturais, onde se defronta com forças fabulosas e acaba por conseguir um triunfo decisivo. Ao regressar de suas misteriosas façanhas, ao completar sua aventura circular, o herói acumulou energias suficientes para ajudar e outorgar dádivas inesquecíveis a seus irmãos.

\subsection{Epítetos}

Entendendo o mito como relato simbólico do surgimento dos objetos, instituições, costumes, houve a preocupação classificatória de ações heroicas ou divinas. Daí, advém o epíteto, que são registros de ritos de passagem, que fazem a divindade ou o herói atualizarem condições primordiais de suas existências: formas de anagnórise ou reconhecimento, seguidas de peripécia, que é alteração do curso dos acontecimentos, mudando o modo de agir dos personagens envolvidos, como certamente diria Aristóteles, in Poétique. Tal é a importância do epíteto e com o qual os gregos reverenciavam Apolo com mais duzentos e, dado o prestígio apolíneo, tornou Delfos um Centro ${ }^{4}$, pois de todos os lugares convergiam fiéis, buscando Delfos para ouvirem do exegeta nacional (PLATÃO, 1996: 427 b), um oráculo, através da Pítia ou Pitonisa; num destes seus atos, recebeu o epíteto Lóxias, mas cujas respostas aos consulentes eram, por vezes, ambíguas, donde o epíteto de ^óxíac (Loksías), Lóxias, oblíquo, equívoco. (BRANDÃO, V. II, 1987: 86)

O episódio de Creso é exemplar, numa manifestação da linguagem em que se dá a simbologia de uma fonte de equívocos, indicativos de nossa subjetivação como uma prisioneira da doxa. Assim, ao perguntar à Pítia sobre quem (BRANDÃO, V. II, 1987: 98) destruirá um grande império, Creso (s. VI a.C.), rei da Lídia, em guerra contra Ciro, rei da Pérsia, ouviu que Se Creso cruzar o rio Hális, destruirá um grande império. Creso, pressionado pela doxa, já que o consenso ditava uma certa superioridade helênica, supôs que o império a ser destruído seria o do seu inimigo, rei Ciro da Pérsia, mas não foi. O dele é que foi dizimado.

\footnotetext{
4 É uma atribuição simbólica de alto valor de crença a um ponto, tomado como sagrado, em sua condição de axis mundi, eixo do mundo. (ELIADE, 1991: 23)
} 
De modo que, para lermos sobre o mito apolíneo, precisamos do testemunho dos poetas, e sendo assim, a pesquisa de Junito de Souza Brandão se apoiou em Homero, Hesíodo e tantos outros poetas, inclusive latinos. Uma das ações de Apolo é vingar as injúrias sofridas por sua mãe Leto, por isso, matará, auxiliado pela irmã Ártemis, Píton a flechadas, e, então, há de fundar um Centro para toda a Grécia, onde a divindade se manifeste: em Delfos: o 'omphalós', o umbigo do mundo. Para nascer os gêmeos Apolo e Ártemis, só havia um único lugar: a flutuante ilha de Ortígia, que não era presa à Terra, e após o nascimento deles, Apolo que se comoveu com a acolhida da ilha, mudou-lhe o nome de Ortígia para Delos, tornando a ensolarada ilha um primeiro Centro do mundo.

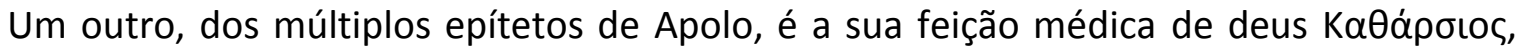
'Kathársios', um purificador da alma, que a libera de suas nódoas. (BRANDÃO: v. II, p. 86)

Comentemos, ainda que com brevidade, sobre psicanálise, conforme juízo de Sigmund Freud (1856 - 1939), criador do termo:

No sentido lato, [a psicoterapia é] qualquer método de tratamento das desordens psíquicas ou corporais que utiliza meios psicológicos e, mais precisamente, a relação entre o terapeuta e o doente: a hipnose, a sugestão, a reeducação psicológica, a persuasão, [psicodrama] etc.; neste sentido, a psicanálise é uma forma de psicoterapia." (LAPLANCHE E PONTALIS: PSICOTERAPIA)

Retomemos, ainda em síntese. o movimento hippie, na década 60, principalmente nos Estados Unidos. Eles pregavam o amor livre, a paz, respeito à natureza, resumindo: fundaram a contracultura. Superavam este isolamento, ou melhor, esta separação, com o uso de drogas alucinógenas... seria uma terapia catártica? Os noticiários da época afirmavam que eles realizavam viagens com a substância LSD (conforme Houaiss Eletrônico: "sigla do inglês: lysergic acid diethylamide"), como se fosse uma viagem "psicodélica", com uma interpretação de viagem a ilha de Delos, que significa etimologicamente visível, isto é, a ensolarada ilha de Apolo.

Donde, dentre tantos epítetos a conquistar, Apolo se torna o Sol, assimilando o deus Hélio, assim como sua irmão Ártemis se torna a Lua, pois a sua mãe Leto era filha da Lua (Febe) e talvez do pai Ceos, talvez com o sentido de Céu luminoso, como está em BRANDÃO: v. II, p. 57.

Mas ainda sobre a sedução pela predestinação da palavra com um certo poder oracular será explorado pelos autores em relação à fruição da obra literária. É assim que os antigos e 
modernos, tomam, a etimologia para estruturação de enunciação. Com tom sublimado em Vergílio, na sua Eneida, que através de uma corruptela etimológica, mas de alto valor poético, associou "Iulus" [isto é, em minúsculas "iulus"], neto de Vênus, a "Iulius Caesar", dando "status" divino a Júlio César:

\footnotetext{
"Nascetur pulchra Troianus origine Caesar, Imperium Oceano, famam qui terminet astris, Iulius, a magno demissum nomen lulo. (En. (, 286-8) Nascerá César de nobre origem troiana, Que limitará o seu governo ao Oceano e sua fama aos astros, O nome Júlio é proveniente do grande lulo."
}

Note-se o futuro do presente do indicativo português na estruturação da enunciação. Como se sabe, o futuro do presente português não é uma continuidade latina. Antes uma criação românica, cujo aspecto verbal do Latim Clássico foi diluído morfologicamente, dada a natureza analítica portuguesa, isto é, a locução verbal portuguesa, que exprime a ideia modal de desejo de nascer, correspondendo no latim vulgar a nasci habet, há de nascer - aglutinada em nascerá - com prevalência modal (CÂMARA JR., 1976: 130), dado que o modo indicativo denota certeza, ou indicação de sentido catagórico em oposição à forma sintética do latim, nascetur, ação verbal imperfectiva, isto é, a se realizar e que exprime o esforço épico de uma construção, por seu valor inconcluso: conotando, pois, no verso de Vergílio a noção de ação em construção.

Enfim, a construção das altae moenia Romae, altas muralhas de Roma, é recitada na proposição. A grandeza heroica de Eneias, filho da deusa Vênus, com lágrimas constrói o seu caráter piedoso e há de superar com lágrimas dificuldades, como a de se privar Creúsa, por decreto dos deuses, bem como quase se privando do pai, conforme se recita no Canto II, verso 651:: Nos contra effusi lacrimis (...), nós [Eneias e família], ao contrário [de seu pai Anquises, prestes a desistir da jornada], [Eneias e família] banhados em lágrimas (...). Porém, sua piedade superou maiores obstáculos, como a objeção implacável da esposa de Júpiter: Juno. Tal epíteto, o piedoso, significa aquele que reverencia os atos divinos e é capaz resgatar os troianos como patriarca de Roma. 


\subsubsection{Epíteto em forma de um Trickster}

No canto VIII da Odisseia, Ulisses ainda está acolhido como hóspede do rei Alcínoo e, ao ouvir o aedo Demódoco cantando os seus feitos, a partir do pedido do próprio Ulisses, no verso 487, que ao ouvir o canto dos relatos troianos se emociona, mas só assume uma enunciação no canto IX, que é um flashback de um encontro do herói com Polifemo. Diz, então seu nome, com a expressão Eu sou Ulisses, verso 17, para o rei dos feaces, Alcínoo, que Ihe oferecera hospedagem. Passa a narrar, então, como foi episódio de Polifemo, Odisseia, IX, 106-547. O Ciclope ${ }^{5}$ Polifemo é filho de Posídon, que, conforme Homero, vivia afastado dos outros ciclopes, Olhicirculares (Odisseia, IX, v. 125), sozinho numa gruta, não precisando plantar e nem cuidar do rebanho, de onde tirava seu sustento.

De modo que o herói heleno aporta sem querer nesta ilha e trata de fazer um reconhecimento com seus doze companheiros. Chegados à gruta, se aproveitaram da fartura dos alimentos, mas foram surpreendidos pelo antropófago Polifemo, que os aprisionou. Após devorar seis dos doze companheiros do nauta grego e ao receber das mãos deste um vinho generoso e saboroso, porém forte, pergunta quem era o grego do vinho: Dá-me outra dose de bom grado e diz teu nome (verso 355). Há muito contrariado pelo desrespeito do Ciclope à lei fraternal da hospitalidade, Ulisses o envolve no seu sinal heroico ${ }^{6}$, isto é: enreda Polifemo numa rede de razões para que a sua enunciação encontre interação social definitivamente, bisneto que era de Hermes, o deus dos ardis e das trapaças, um trickster, ou seja, 'polýmētis', malicioso e hábil, e 'polýtropos', solerte e manhoso, verso 366: Ninguém me denomino. Então, ouve como resposta que será devorado por último e depois dos seus companheiros, dada a gratidão pela gentileza do vinho... e como xênia, quer dizer, acolhimento afetuoso para hóspedes. Quer dizer, a ironia homérica subjaz na enunciação.

\footnotetext{
${ }^{5}$ Note a etimologia do termo ciclope: composto de 'kýklos', "círculo, o que é redondo" e de (...) 'ôpa', (a forma de nominativo é 'ops') "olho", donde "o que tem um grande olho redondo" e a sua breve ação mítica: por lutarem ao lado de Zeus, obtiveram a liberdade. Gratos, concederam a Zeus, o trovão, o relâmpago e o raio; a Hades ou Plutão, um capacete que o tornava invisível; a Posídon, o tridente. (BRANDÃO, 1991: CICLOPES)

${ }^{6}$ Os epítetos homéricos têm uma relevância mais consistente do que a simples formalização métrica e função mnemônica para os aedos, elementos tão defendidos nos manuais tradicionais de literatura. Eles denotam a areté, a "excelência", e timé, "a honra pessoal", já que, como arquétipos que são de nossa condição precária, os heróis suprem, nos epítetos exemplares, nossas deficiências.
} 
Pelo fato de alguém ser possuidor de um terceiro olho, seria dotado de clarividência, que se opõe ao normal: ser dotado de dois olhos. Mas, neste episódio homérico, ser dotado de um único olho simboliza (CHEVALIER \& GHEERBRANDT, 1994: CICLOPE) uma recessão da inteligência, (...) ou a perda do sentido de certas dimensões e de certas analogias. Ter um olho, ou até mesmo um terceiro olho, pode ser não uma condição física, mas uma competência espiritual do Homem em dada instância do olhar: o de um só olho é uma não percepção plena dos órgãos dos sentidos, como a situação de Polifemo, aliás, censurado por Ulisses pelo desrespeito à lei da hospitalidade e pelo mau humor no seu relacionamento social. Mau humor que o isola dos outros ciclopes e, até mesmo, da possibilidade do convívio social com outros humanos, como acentuou Ulisses numa passagem do encontro, o que aliás é uma estratégia enunciativa de Homero, como se verá abaixo.

Essa produção da agressão daqueles seres de um só olho gera uma reação contrária e em sentido oposto, e toma por escudo um irônico Ninguém. Com o ambíguo Ninguém, ora como escudo, ora como ataque, Ulisses derrota a voracidade brutal de Polifemo. Eis a máscara, sendo esses deslocamentos e condensações uma máscara poética. Quanto mais Polifemo gritasse Ninguém me fere com astúcia, não com força(v. 408) e os outros Ciclopes, em réplica, disseram: Se, então, ninguém te agride e estás sozinho, (..) (v.410) foram embora abandonando Polifemo aos gritos... Enfim, Homero descreve mais um truque do trickster Ulisses: eles escaparam, usando o artifício de se esconderem embaixo das ovelhas, enquanto isso Polifemo passava a mão por cima do dorso delas e as tangia para pastarem...

Levantamos a hipótese da percepção fora da condição física de um indivíduo qualquer, porque um ser vivo pode não se aperceber do que se passa em torno de si, mesmo que esteja olhando para o objeto bem na sua frente. Assim, este objeto deveria ser apreendido ou captado pelos sentidos, e sabe-se que a visão é tida como o mais apurado dos órgãos do sentido; no entanto, falta-lhe um traço empírico, de valor mnemônico. É desse modo que, às vezes, encontramos indivíduos com aparência normal, ou seja, com dois olhos, mas inteiramente broncos no que tange ao relacionamento social. E isso independe de sexo, grau de inteligência e escolaridade. Isso de se medir a inteligência das pessoas, por exemplo, porque tire dez em Matemática, pode ser parâmetro equivocado. 
Para Kant (1724 -1804), há uma realidade sensível, perceptível e palpável, que é o fenômeno ou a coisa em si, tal como existe, e outra, transcendental, que é o númeno - coisas que existem só no entendimento, ou na intuição. São de cunho subjetivo.

\subsubsection{A nobreza das lágrimas}

Na Literatura Brasileira, são muitas as poesias, dado o espaço, mas só citaremos aqui Antônio GONÇALVES DIAS (1823 - 1864), I Juca-Pirama, embora tenhamos o poema épico Os Timbiras, que foi cunhado pelo próprio poeta de lliada Brasileira (MOISÉS e PAES: TIMBIRAS, OS), porém inacabado. Assim como os antigos gregos, os heróis românticos eram dotados de 'agón', termo que é um grecismo: assembleia; luta, combate; debate, questão; momento crítico presente em nosso termo agonia. Este espírito agônico é simbólico da hospitalidade, o que é uma lei divina numa sociedade arcaica, como a dos helenos, uma vez que se fixavam reuniões periódicas com libações aos deuses e confraternização entre os cidadãos de pontos longínquos e diversos da dispersa geografia grega, fortalecendo entre eles os laços amizade.

Além disso, as sociedades primitivas também cultuavam o combate, a coragem e a energia, como símbolos de um herói épico.

Surge no Romantismo uma atmosfera fomentadora dos sentimentos e prevalência da emoção sobre a razão, bem como o retorno à natureza. Na Europa, revalorização da Idade Média e, por conseguinte, o ressurgimento do cavalheirismo, análogo ao cavalheirismo homérico e olímpico. No Brasil, a Independência do Brasil em 1822 e sua consolidação estimulam o nacionalismo, mas, pela falta da Idade Média, o nacionalismo nos anima o olhar para o que havia de mais nacional: o índio. O Indianismo sustentou-se sob a égide do bom selvagem, ideal de Jean Jacques Rousseau (1712 - 1778), ao afirmar que o homem é naturalmente bom e a sociedade o corrompe.

Gonçalves Dias focalizou o nosso aborígine com o mesmo significado sugerido por Rousseau: o bom selvagem. $E$, na criação de um discurso nacional, se valeu, dentro dessa inédita realidade do Novo Mundo, a América, da onomatopeia, termo grego, que significa, a rigor, a ação de criar palavras novas, enriquecendo o nosso vocabulário não só com tupinismos, mas também com revigoramento da significação. 
O seu poema I - Juca-Pirama7, composto de dez partes, apresenta uma nota dada pelo próprio Autor a respeito do título: O título desta poesia, traduzido literalmente da língua tupi, vale tanto como se em português disséssemos "o que há de ser morto, e que é digno de ser morto". Esta explicitação do Vate maranhense é a medida de sua preocupação em demonstrar que um epíteto nativo brasileiro ombrearia em termos de dignidade heróica com qualquer outro herói, cavalheirescamente, seja pertencente à Idade Média ou à clássica Grécia.

Como introdução, Parte I, há uma descrição das tabas dos timbiras, em sextilhas. É inegável a marca do estilo épico do Renascimento no vocabulário erudito, ao longo das dez partes. Buscam-se termos carreados de energia, à moda de Camões, consagrado como modelo e que escreveu rudo, que é a forma do português arcaico que aparece tanto na medida nova camoniana quanto no indianismo gonçalvino, logo no primeiro verso da segunda estrofe: São [os timbiras] rudos, severos, sedentos de glória; (...) Em realce uma expressão erudita, com datação 1664 prélios (verso seguinte); além de mais neologismos, caracteristicamente camonianos ${ }^{8}$, nos versos, ainda sobre o brio dos timbiras, ainda nesta segunda estrofe, da Parte I:

Seu nome lá voa na boca das gentes, Condão de prodígios de glória e terror!

em que o termo condão provém do latim condonare, dar como presente, donde o sentido de dádiva; no segundo verso, na quarta estrofe, da primeira parte, aduna o concílio guerreiro, ou seja, a épica assembléia reunida para decisões superiores; na estrofe seguinte: escravo insulano, numa manifesta comparação com evento da Grécia ${ }^{9}$; na oitava estrofe, Parte I, A coma lhe cortam, além do simbolismo do corte de cabelo, comum em ritos de passagem na arcaica Grécia e na comunidade primitiva, aí nos deparamos com o helenismo "kóme', pelo latim "coma", cabeleira; coortes, denotando batalhões. Desse modo, a constelação de feitos sublimados: prélios, condão de prodígios, significando ações heroicas, como em Homero 'cléa andrôn', os feitos dos heróis, ou até mesmo res gestas Caesaris, feitos gloriosos de César.

\footnotetext{
7 DIAS, Antônio Gonçalves. Poemas de Gonçalves Dias.

8 Luís Vaz de Camões se consagrou justamente porque restaurou a língua portuguesa, enriquecendo-a ou relatinizando-a.

${ }^{9}$ Assim lá na Grécia ao escravo insulano ( $4^{\circ}$. verso da $5^{\mathrm{a}}$. estrofe)
} 
Porém, o ritmo é essencial no seu poema. Na expressão de Afrânio Coutinho, na segunda parte, é como se ouvíssemos a dança, o batepé dos selvagens no festim, ${ }^{10}$ conforme a associação do verso decassílabo ao curto de rima aguda. Nesta segunda parte, concluindo a descrição do preparo ritual, propõe o Poeta uma espécie de monólogo, como se uma voz a perguntar a respeito das preocupações do valente guerreiro tupi e a sua expectativa de morte, devido à tradição de sua situação de prisioneiro neste exato momento; a voz que o indagou há pouco, ressalta o Poeta o encontra, na quarta estrofe, de Contudo os olhos d'ignóbil pranto / Secos estão (...) Ele, semelhante à situação de Ulisses, mencionada mais acima, só pranteará em uma singular situação; portanto, não de medo perante a morte.

Com efeito, encontra-se conduzido a um rito de passagem, uma vez que toda essa preparação seria para um banquete, em que o cativo, por ser um bravo, e em especial um tupi, será devorado pelos timbiras, a fim de que todos os guerreiros assimilem a coragem e a energia tupi. Assim, uma sociedade primitiva se comporta como agonística (pelo latim agonisticu: scilicet, arte, significando a arte da luta na antiga Grécia). Ou seja, a definição do cacique da tribo se concebe pela sua força de guerreiro valente. Para ilustrar, dispomos abaixo duas estrofes:

II

Em fundos vasos d'alvacenta argila

Ferve o cauim;

Enchem-se as copas, o prazer começa,

Reina o festim.

O prisioneiro, cuja morte anseiam, Sentado está,

O prisioneiro, que outro sol no ocaso Jamais verá!

(...)

Passemos a Parte III, no pescoço do orgulhoso cacique há um colar de alvo marfim:

(...)insígnia de honra, Que lhe orna o colo e o peito, ruge e freme, Como que por feitiço não sabido Encantadas ali as almas grandes Dos vencidos Tapuias, inda chorem; Serem glória e brasão d'imigos feros.

10 COUTINHO, Afrânio. Volume II, p. 101. 
(Parte III, primeira estrofe).

O 'agón', que principiou com a introdução resumida mais acima, continua com o desafio do cacique, nesta parte III, após a descrição na primeira estrofe acima:

As nossas matas devassaste ousado, Morrerás morte vil da mão de um forte.

O guerreiro Tupi está no meio do terreiro e ouve o desafio do valente chefe timbira, ainda nesta Parte III, uma apresentação épica:

Dize-nos quem és, teus feitos canta,

Ou se mais te apraz, defende-te.

Exatamente como nos encontros de heróis da épica clássica, grega e latina, quando relatavam, na apresentação identitária, a sua genealogia, epítetos, os quais são a síntese dos seus feitos heroicos.

Há neste poema uma variação métrica com objetivo de ressaltar o ritmo. É o caso da quarta parte apresentada em redondilha menor e a sugestão rítmica de um tom marcial de instrumentos de percussão, sintonizando o discurso do bravo guerreiro tupi. No entanto, um paradoxo! Pede que seja poupado da conclusão do ritual, ainda na quarta parte:

Meu canto de morte, Guerreiros, ouvi:

Sou filho das selvas, Nas selvas cresci;

Guerreiros, descendo

Da tribo Tupi.

Andei longes terras, Lidei cruas guerras, Vaguei pelas serras Dos vis Aimorés; Vi lutas de bravos, Vi fortes - escravos! De estranhos ignavos Calcados aos pés.

Aos golpes do imigo Meu último amigo, 
Sem lar, sem abrigo

Caiu junto a mi!

Com plácido rosto,

Sereno e composto,

$\mathrm{O}$ acerbo desgosto

Comigo sofri.

Meu pai a meu lado

Já cego e quebrado,

De penas ralado,

Firmava-se em mi:

Nós ambos, mesquinhos,

Por ínvios caminhos,

Cobertos d'espinhos

Chegamos aqui!

O velho no entanto

Sofrendo já tanto

De fome e quebranto,

Só queria morrer!

Não mais me contenho,

Nas matas me embrenho,

Das frechas que tenho

Me quero valer.

Então, forasteiro,

Caí prisioneiro

De um troço guerreiro

Com que me encontrei:

O cru dessossego

Do pai fraco e cego,

Enquanto não chego,

Qual seja - dizei!

Eu era o seu guia

Na noite sombria,

A só alegria

Que Deus Ihe deixou:

Em mim se apoiava,

Em mim se firmava,

Em mim descansava,

Que filho lhe sou.

Ao velho coitado

De penas ralado,

Já cego e quebrado,

Que resta? - Morrer.

Enquanto descreve 
O giro tão breve

Da vida que teve,

Deixa-me viver!

Não vil, não ignavo,

Mas forte, mas bravo,

Serei vosso escravo:

Aqui virei ter.

Guerreiros, não coro

Do pranto que choro;

Se a vida deploro,

Também sei morrer.

Embora afirme não ser um covarde por pedir algumas horas de sobrevivência, pois, por ser arrimo e, devido à cegueira e velhice do pai dependente unicamente dele, pede para viver, pois assim amparará o pai. Era ele mesmo quem the restava ainda como guia e amparo nos desafios da densa floresta. Porém, mesmo prometendo retornar e cumprir a escravidão de sua prisão, causa admiração a todos quando o cacique ordena que o solte (V parte, na primeira palavra e primeira reação do cacique): Soltai-o! Mas, com nova alternância métrica para decassílabos desta Parte $\mathrm{V}$, quando o tupi se dirige ao chefe dos timbiras para agradecer o julgamento, obtém a seguinte resposta peremptória:

- Mentiste, que um Tupi não chora nunca,

E tu choraste! (...) parte; não queremos

Com carne vil enfraquecer os fortes.

O seu fôlego de tupi supera situação tão humilhante. É desse modo que o bravo tupi penetra na floresta. Ao aproximar-se do pai, oferece-Ihe provisões, a fim de restaurar-Ihe forças perdidas.

E um reconhecimento, na Parte $\mathrm{Vl}$, onde não há o rigor de estrofes delineadas, o pai não convencido das explicações do filho e, quem perde a visão, tem a compensação do olfato aguçado:

sente $o$ acre odor das frescas tintas, Uma idéia fatal correu-lhe à mente (...)

Reconhece, ao apalpar ornato macio de penas no corpo do filho, os indícios de um ritual de passagem. Recusa a idéia momentaneamente, para, em seguida confirmar no toque de sua 
mão uma cabeça com corte de cabelo. Não havia dúvida: - Tu prisioneiro, tu? E a confissão: - Vós o dissestes ${ }^{11}$. Confessa que a nação fora a dos timbiras. - E a muçurana funeral rompeste(...) 0 velho tupi solicita a posição da taba dos timbiras, faz o filho marchar em sua direção. Apresentase ao chefe e, num breve relato das ocorrências, pede, na sétima parte, com versos em redondilha maior, com a extensão de estrofe conveniente ao tamanho do diálogo:

$$
\begin{gathered}
\text { a lenha, o fogo, } \\
\text { A maça do sacrifício } \\
\text { E a muçurana ligeira: } \\
\text { Em tudo o rito se cumpra! } \\
\text { Retruca o cacique: } \\
\text { — Nada farei do que dizes: } \\
\text { É teu filho imbele e fraco } \\
\text { Aviltaria o triunfo } \\
\text { Da mais guerreira das tribos } \\
\text { Derramar seu ignóbil sangue: } \\
\text { Ele chorou de cobarde; } \\
\text { Nós outros, fortes Timbiras, } \\
\text { Só de heróis fazemos pasto. }
\end{gathered}
$$

Ao saber, na parte VIII, que o filho de um tupi chorou na presença de um estranho, renegao como filho, a tal ponto de desejá-lo prisioneiro dos vis Aimorés, oitava parte. A reação foi de imediato. A voz do filho ecoa, na Parte IX:

Da sua noite escura as densas trevas Palpando. - Alarma! alarma! - O velho pára!

O grito que escutou é voz do filho,

$$
\text { (...) }
$$

Atente-se no rigor da morfologia como escolha estilística de Gonçalves Dias, quando, como se estivesse esculpindo, o seu cinzel imprime ao empréstimo do italiano em vogal temática -a, alarma e a precisão etimológica da expressão italiana alle arme, para as armas.

O pai, agora honrado - um equivalente heroico da 'timé' grega, na parte IX, em pranto copioso, / Que o exaurido coração remoça. Este choro é como o do filho, tem o mesmo significado anterior, em que se depreendeu, equivocadamente, um ato de covardia, medo perante a morte.

\footnotetext{
11 Note-se o plural de cerimônia em segunda de plural, pois o seu auditório é o venerando pai, além disso, uma ênfase como confirmação da anagnorise aristotélica. (CUNHA \& CINTRA, 2017, p. 299).
} 
São outras lágrimas. São (...)- estas lágrimas, sim, que não desonram., diz o pai, ainda na parte IX. E sob o-Basta! do chefe dos Timbiras, reconhecendo o cacique o ímpeto de um guerreiro e, portanto, a bravura de um tupi.

Na parte dez, com alternância de versos longos e curtos, cadenciando o relato pedagógico do ancião da tribo dos Timbiras como se fosse um aedo ou rapsodo:

Um velho Timbira, coberto de glória, Guardou na memória

Do moço guerreiro, do velho Tupi!

$\mathrm{E}$ à noite, nas tabas, se alguém duvidava

Do que ele contava,

Dizia prudente: - Meninos, eu vi!

Note-se um dado: a valorização da memória. A memória é a mídia entre as sociedades arcaicas ou primitivas. A modernidade do terceiro milênio desconhece a memória no sentido destes versos gonçalvinos, tanto que, retirada das escolas atualmente o cultivo da memorização, sob uma nova orientação, que insiste pejorativamente em difamá-la com a expressão "decoreba", há, paradoxalmente, cursos de memorização anunciados com frequência em propagandas. Neste sentido, as sociedades de língua ágrafa preservam a sua história como aponta Gonçalves Dias acima. Tantas vezes a história seria contada quantas vezes fossem necessárias. Por isso, Gonçalves Dias fecha a parte X, com o estribilho Meninos, eu vi!:

Assim o Timbira, coberto de glória, Guarda a memória

Do moço guerreiro, do velho Tupi, E à noite nas tabas, se alguém duvidava do que ele contava,

Tornava prudente: "Meninos, eu vi!"

E o termo prudente está como no latim: providens ${ }^{*}$ proudens>prudens, que prevê; que sabe.

\section{Considerações finais}

Ao longo da exposição, se observaram várias características épicas de Homero pontuando intertextualmente e se configurando em epítetos dos personagens centrais quer épicos, quer 
dramáticos e, por vezes, em romances. Interdisciplinarmente, cruzamos elementos etnográficos, históricos, filosóficos, míticos etc. para realçar a alteridade cultural.

Demonstrou-se ainda a História registrando paradoxos culturais: personalidades ciclópicas como as de Nero, que foi preparado por Sêneca, o Filósofo, ou até mesmo a de Hitler, que também teve uma iniciação excelente na educação. Não se quer, com estas considerações, tematizar a educação. Não. As nossas observações são específicas sobre a personalidade ciclópica.

Os epítetos de Homero a Gonçalves Dias centralizaram o sentido em torno do herói, tornando-se uma senha para os grandes feitos, como a focalização dramática vivida por I JucaPirama, que era último descendente da tribo tupi, bem como, em geral, para leitura dos textos frequentados.

\section{Bibliografia}

ALBUQUERQUE JUNIOR, Durval Muniz de. A invenção do Nordeste e outras Artes. São Paulo: CORTEZ, 2011.

ARISTOTE. Poétique. Texte établi et traduit par J. Hardy. Paris: Les Belles Lettres, 1932.

BARTHES, ROLAND. O Rumor da língua. Tradução de Maria Laranjeira. São Paulo: Brasiliense, 1988.

BÍBLIA (Edição Pastoral). Tradução de Ivo Storniolo e Euclides M. Balancin.São Paulo: Paulus, 1990.

BRANDÃO, Junito de Souza. Mitologia Grega. Petrópolis: Vozes, 1986. 3 v.

. Dicionário Mítico-etimológico da Mitologia Grega. Volume I A- I. Petropólis: 1991.

CÂMARA JÚNIOR, Joaquim Mattoso. História e Estrutura da Língua Portuguesa. Rio de Janeiro: Padrão, 1967.

CHANTRAINE, Pierre. Dictionnaire Étymologique de la langue Grecque. Paris: Klincksieck, 1999. CHEVALIER, J. \& GHEERBRANDT, A. Dicionários de Símbolos. Trad. Vera Silva, Raul de Sá Barbosa, Angela Melim e Lúcia Melim. Rio de Janeiro: José Olympio, 1994.

COUTINHO, Afrânio. A Literatura Brasileira: Romantismo. Rio de Janeiro: Sul Americana, 1969. V.II.

CUNHA, Celso \& CINTRA, Lindley. Nova Gramática do Português Contemporâneo. Rio de Janeiro: Lexicon, 2017.

DELLA CORTE, Francesco. La Filologia Latina: Dalla Origini a Varrone. Firenze: La Nuova Italia, 1981.

DIAS, Antônio Gonçalves. Poemas de Gonçalves Dias. Rio de Janeiro: Edições de Ouro, s/d. 
ELIADE, Mircea. Mito do Eterno Retorno. Tradução de José A. Ceschin. São Paulo: Mercuryo, 1991.

ERNOUT, A. \& MEILLET, A. Dictionaire Étymologique de la Langue Latine: Histoire de Mots. Paris: Klincksieck, 1985.

HOMERO. Odisseia. Edição bilingue. Tradução, posfácio e notas de Trajano Vieira. São Paulo: Editora 34, 2011.

HOUAISS, A. Dicionário eletr. Houaiss da I. portuguesa. RJ: Objetiva. V.1.0 [CD-ROM], 2009.

HYDE, Lewis. A Astúcia Cria o Mundo: "Trickster" - Trapaça, Mito e Arte. Rio de Janeiro. Tradução de F. R.S Innocêncio e Marina Vargas. Civ. Brasileira, 2017.

JAPIASSÙ, Hilton e MARCONDES, Danilo. Dicionário Básico de Filosofia. RJ: Jorge Zahar, 2006.

LAPLANCHE, J. \& PONTALIS, J.-B. Vocabulário da Psicanálise. Tradução de Pedro Tamen. Colaboração na terminologia: Dr. João Santos.São Paulo: Martins Fontes, 1988.

MOISÉS, Massaud. Dicionário de Termos Literários. São Paulo, Cultrix, 1974.

e PAES, José Paulo (Org.). Pequeno Dicionário de Literatura Brasileira. São Paulo, Cultrix, 1980.

PEREIRA, Isidro. Dicionário Grego-Português e Português-Grego. Porto: Apostolado da Imprensa, 1976.

PLATÃO. A REPÚBLICA. Tradução e notas de Maria Helena da Rocha Pereira. Lisboa: Fundação Calouste Gulbenkian, 1996.

PORTELLA, Eduardo et alii. Teoria Literária: Planejamento e Coordenação de Eduardo Portella. Rio de Janeiro: Tempo Brasileiro, 1979.

SECCHIN, Antonio Carlos. Percursos da Poesia Brasileira: Do Século XVIII ao XIX. Belo Horizonte: Antêntica (UFMG), 2018.

SILVA, Anazildo Vasconcelos. Formação Épica da Literatura Brasileira. Rio de Janeiro: Elo, 1987.

STAIGER, Emil. Conceitos Fundamentais da Poética. Tradução de Celeste A. Galeão. Rio de Janeiro: Tempo Brasileiro, 1972. 